\title{
ROLA I ZNACZENIE METODY OTWARTEGO DIALOGU W ŚRODOWISKOWYCH CENTRACH ZDROWIA PSYCHICZNEGO
}

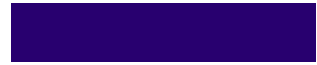

DAGMARA BARTCZAK-SZERMER *

Instytut Psychologii, Uniwersytet Kardynała Stefana Wyszyńskiego

w Warszawie

Wydział Medyczny, Uczelnia Łazarskiego w Warszawie

TOMASZ ROWIŃSKI

Instytut Psychologii, Uniwersytet Kardynała Stefana Wyszyńskiego w Warszawie
\end{abstract}

\section{STRESZCZENIE}

Transformacja w zakresie opieki psychiatrycznej, która nastąpiła na przełomie lat 80. i 90. XX wieku w Finlandii, przyniosła wymierne efekty, zaimplementowane potem w innych krajach. Obniżenie odsetka osób chorujących na schizofrenię, istotne zmniejszenie zapotrzebowania chorych na stosowanie farmakoterapii i redukcja kosztów opieki psychiatrycznej - przez pracę ze specjalistycznym zespołem terapeutycznym i zaangażowanie najbliższego otoczenia osób doświadczających kryzysów psychicznych w proces podejmowania decyzji dotyczących leczenia - stanowią podstawę modelu opieki środowiskowej. Model ten zyskuje coraz większą popularność także i w Polsce. Metoda Otwartego Dialogu (ODA), zgodna z założeniami deinstytucjonalizacji oraz budowania sieci wsparcia w lokalnym środowisku, została wprowadzona do naszego kraju przez Fundację Polski Instytut Otwartego Dialogu. ODA promuje oddziaływania psychospołeczne i terapeutyczne, w których farmakoterapia nie jest metodą pierwszego wyboru. Artykuł porusza kwestie zarówno przeobrażenia opieki psychiatrycznej, jak i metod terapeutycznych, które są efektywnie wykorzystywane przez Środowiskowe Centra Zdrowia Psychicznego. W nowym modelu opieki wspólpraca specjalistów, zaangażowanie otoczenia społecznego oraz koncentracja na wykorzystaniu zasobów środowiska osób dotkniętych kryzysem psychicznym stanowią szansę na istotny wzrost jej efektywności.
METODA OTWARTEGO DIALOGU OPIEKA ŚRODOWISKOWA ŚRODOWISKOWE CENTRA ZDROWIA PSYCHICZNEGO ZABURZENIA PSYCHICZNE
7 ROLA IZNACZENIE METODY OTWARTEGO DIALOGU W ŚRODOWISKOWYCH CENTRACH ZDROWIA PSYCHICZNEGO

7 ROZPOWSZECHNIENIE I KOSZTY EKONOMICZNE ZABURZEŃ PSYCHICZNYCH

8 OSOBY W KRYZYSIE PSYCHICZNYM A SYSTEM OPIEKI PSYCHIATRYCZNEJ

9 Model środowiskowy

10 Otwarty Dialog

14 Otwarty Dialog w Polsce

14 Otwarty Dialog i Środowiskowe Centra Zdrowia Psychicznego

15 PODSUMOWANIE

16 BIBLIOGRAFIA 


\title{
THE OPEN Dialogue IN COMMUNITY-BASED MENTAL HEALTH CENTERS: IMPORTANCE OF A NEW APPROACH IN THE TREATMENT OF PSYCHIATRIC PATIENTS
}

\begin{abstract}
The transformation of psychiatric mental health care in late 80s and 90s of the last century in Finland brought the results that were implemented by other countries. Lowering the percentage of people suffering from schizophrenia, a significant reduction in the patient's need for pharmacotherapy, reducing the costs of psychiatric care - by working with a specialized therapeutic team, involving the nearest community of people experiencing mental crises in the process of making decisions about treatment is the basis of the community care model. This model is gaining more and more popularity also in Poland. The Open Dialogue Method (ODA), consistent with the assumptions of deinstitutionalization and building a social support network in the local environment, was introduced to our country by the Polish Institute of Open Dialog Foundation. ODA promotes psychosocial and therapeutic interactions in which pharmacotherapy is not the first choice method. The article addresses the issues of both the transformation of psychiatric care and therapeutic methods that are effectively used by the Community Mental Health Centers. In the new model of care, the cooperation of specialists, the involvement of the social environment and focus on the use of environmental resources of people affected by mental crisis are an opportunity to significantly increase its effectiveness.
\end{abstract}

\section{KEYWORDS}

Open Dialogue Approach, community-based treatment, Environmental Center for Mental Health, psychiatric disorders 


\title{
ROLA I ZNACZENIE METODY OTWARTEGO DIALOGU W ŚRODOWISKOWYCH CENTRACH ZDROWIA PSYCHICZNEGO
}

\begin{abstract}
aburzenia i kryzysy psychiczne są jednymi z największych cywilizacyjnych zagrożeń współczesnego świata (Moskalewicz, Kiejna, Wojtyniak, 2012; Ritchie, Roser, 2018). Zaburzenia zdrowia psychicznego, biorąc pod uwagę rozpowszechnienie, mogą dotyczyć każdego człowieka, niezależnie od jego pochodzenia, stanu zdrowia, płci czy wieku. Upowszechnianie wiedzy na temat kryzysów i zaburzeń psychicznych, w tym w szczególności ich profilaktyka, staje się ważnym aspektem ochrony zdrowia. Dzieje się tak nie tylko dlatego, że zaburzone funkcjonowanie psychiczne jest jednym z czynników ryzyka chorób somatycznych (Ohrnberger, Fichera, Sutton, 2017), lecz przede wszystkim dlatego, że jakość życia, na którą w znacznej mierze składa się jakość funkcjonowania psychicznego, jest przedmiotem konkretnych wdrożeń wiedzy naukowej do praktyki społecznej.
\end{abstract}

\section{ROZPOWSZECHNIENIE I KOSZTY EKONOMICZNE ZABURZEŃ PSYCHICZNYCH}

$\mathrm{Z}$ raportu Health at a glance: Europe 2018, opublikowanego w listopadzie 2018 r. przez Organizację Wspólpracy Gospodarczej i Rozwoju (Organisation for Economic Co-operation and Development [OECD], European Union, 2018), wynika, że w krajach Unii Europejskiej problemy ze zdrowiem psychicznym dotykają ok. $84 \mathrm{mln}$ osób. Oznacza to np., że w 2016 r. jedna na sześć osób doświadczyła problemów ze zdrowiem psychicznym. Dodatkowo stwierdzono, że w Unii Europejskiej tylko w 2015 r. kryzysy psychiczne były przyczyną 84 tys. samobójstw. Przeprowadzone w Polsce epidemiologiczne badanie zaburzeń psychicznych (EZOP; Moskalewicz, Kiejna, Wojtyniak, 2012) wykazało, że u 23\% osób objętych badaniem można w ciąu życia rozpoznać przynajmniej jedno zaburzenie psychiczne z 18 definiowanych w klasyfikacjach ICD-10 i DSM-IV (Kalita, Chrzan-Dętkoś, 2018; Kiejna i in., 2015).

Problemy ze zdrowiem psychicznym mają również konsekwencje ekonomiczne, widoczne na poziomie krajowym. OECD (OECD, European Union, 2018) podkreśla, że w 2015 r. finansowe koszty świadczeń związanych ze złym stanem zdrowia psychicznego mieszkańców Unii Europejskiej przekroczyły ponad 600 mld euro (ponad 4\% PKB). W raporcie uwzględniono zarówno koszty bezpośrednie opieki zdrowotnej (profilaktyka, diagnostyka i leczenie zaburzeń psychicznych - 190 mld euro; 1,3\% PKB), wydatki związane z programami pomocy społecznej (świadczenia, zasiłki społeczne - 170 mln euro; 1,2\% PKB), jak i koszty pośrednie na rynku pracy (niższa stopa zatrudnienia i mniejsza produktywność osób cierpiących na choroby psychiczne -240 mld euro; $1,6 \%$ PKB). W Polsce koszty związane ze złym stanem zdrowia psychicznego przekraczają $12 \mathrm{mln}$ euro (3\% PKB), w tym koszty bezpośrednie obejmujące opiekę zdrowotną to ponad $5 \mathrm{mln}$ euro $(1,2 \% \mathrm{PKB})$, programy pomocy społecznej - ponad $3 \mathrm{mln}$ euro $(0,75 \% \mathrm{PKB})$, koszty pośrednie natomiast związane $z$ rynkiem pracy to ponad $4 \mathrm{mln}$ euro (1,07\% PKB; OECD, European Union, 2018). Różnice we wspomnianych kosztach między krajami Unii Europejskiej (Polska na 13. miejscu) wynikają głównie z odsetka osób, które zgłaszają problemy ze zdrowiem psychicznym, z możliwości uzyskania oraz jakości wsparcia w ramach programów społecznych oraz dostępności i jakości opieki psychiatrycznej (OECD, European Union, 2018). Ponadto od lat 
największą grupę wydatków stanowią koszty społeczne związane z niezdolnością do pracy (w Polsce ponad 16\%; ZUS, 2020). Należy jednak podkreślić, że liczba ta jest niedoszacowana w krajach, w których stygmatyzacja osób doświadczających problemów psychicznych jest zjawiskiem powszechnym.

Tak wysokie koszty bezpośrednie i pośrednie sprawiają, że próby podwyższenia jakości życia i polepszenia zdrowia psychicznego zyskują dodatkową argumentację ekonomiczną. W szczególności podejmowane są próby zwiększenia nakładów finansowych na działania profilaktyczne oraz reorganizację opieki psychiatrycznej. W literaturze wykazuje się, że efektywne działania prewencyjne i profilaktyczne nie tylko istotnie zmniejszają dotychczasowe koszty ponoszone w związku z zaburzeniami psychicznymi, lecz także znacznie przekraczają poziom oczekiwanych korzyści (O'Connell, Boat, Warner, 2009). Jednak w świadomości społecznej dominującym sposobem leczenia psychiatrycznego jest model oparty na izolacji osób cierpiących z powodów kryzysów psychicznych (Sartorius i in., 2010). Ta forma organizacji świadczeń i leczenia wydaje się najmniej efektywna pod kątem zarówno finansowym, jak i poprawy jakości życia osób chorujących (Dieterich i in., 2017; Knapp $\mathrm{i}$ in., 1994; Knapp, Beecham, McDaid, Matosevic, Smith, 2011; Malone, Newron-Howes, Simmonds, Marriot, Tyrer, 2007; Mueser, Bond, Drake, Resnick, 1998; Ziguras, Stuart, 2000).

\section{OSOBY W KRYZYSIE PSYCHICZNYM A SYSTEM OPIEKI PSYCHIATRYCZNEJ}

Dotychczasowe założenia polskiego systemu opieki psychiatrycznej, opartego głównie na lecznictwie zamkniętym, potrzeba wyższych nakładów finansowych, a także wysoki poziom uprzedzeń społecznych wobec osób z zaburzeniami zdrowia psychicznego (Wciórka, Wciórka, 2008) przyczyniły się do poszukiwania w Polsce nowych rozwiązań problemów opieki psychiatrycznej. Ich efektem jest model środowiskowy, zyskujący coraz większe uznanie specjalistów (pracujących także z dziećmi oraz młodzieżą; Goldman i in., 2020; IJzendoorn i in., 2020), wprowadzenie nowych, skutecznych metod terapeutycznych oraz organizacja działań profilaktycznych ukierunkowanych na ograniczenie stygmatyzacji i na wzrost świadomości członków społeczeństwa.

Optymalny system opieki psychiatrycznej powinien uwzględniać odpowiednie procedury szybkiego i właściwego reagowania na kryzys psychiczny. Kryzysy psychiczne nieodłącznie towarzyszą procesom rozwoju i dojrzewania człowieka i mogą występować w sytuacjach nagłych i nieprzewidywalnych. Definicje kryzysu podkreślają, że wystąpienie stanu braku równowagi o znaczeniu krytycznym jest uwarunkowane nie przez samo wydarzenie stresogenne, ale przez nadmiar obciążenia emocjonalnego, który uniemożliwia podjęcie efektywnych działań (Felgoise, Nezu, Nezu, Reinecke, 2005). Współczesne, różnorodne koncepcje kryzysu dotyczą m.in. utraty lub zaburzenia równowagi emocjonalnej, psychicznej, braku efektywnych strategii radzenia sobie w sytuacji zagrażającej czy też przełomowego, krytycznego, zwrotnego momentu w życiu (Heszen-Niejodek, 2002). Wspólnym mianownikiem wszystkich koncepcji kryzysu jest ryzyko doświadczenia dysfunkcji w obszarze poznawczym, emocjonalnym i behawioralnym o charakterze ostrej dekompensacji, wymagających zastosowania profesjonalnych i skutecznych metod $\mathrm{w}$ celu odzyskania równowagi oraz autonomii (Caplan, 1964).

Według Caplana (1964) utrata równowagi oraz dezorganizacja funkcjonowania stanowią podstawę kryzysu, który jest skutkiem braku możliwości przezwyciężenia napotkanych trudności za pomocą dotychczas stosowanych metod rozwiązywania problemów. Caplan podkreślał też, że kryzys, odnoszony do emocjonalnego funkcjonowania człowieka, nie jest reakcją patologiczną, lecz adaptacyjną - zwróconą ku odzyskaniu wewnętrznej równowagi. 
Dynamika zjawiska kryzysu umożliwiła wyróżnienie charakterystycznych dla niego faz. W pierwszej fazie obserwuje się wzrost odczuwania niepokoju jako reakcję na wystąpienie wydarzenia o charakterze stresującym. W tej fazie rozpoczyna się także inicjacja zachowań zaradczych mających na celu redukcję odczuwanego napięcia. Nieefektywne metody radzenia sobie w sytuacji stresującej powodują nasilenie negatywnych emocji (faza druga). Eskalacja odczuwanego napięcia jest charakterystyczna dla trzeciego etapu rozwoju kryzysu - odczuwany dotychczas niepokój zmienia się w lęk, a znane i uruchomione mechanizmy zaradcze nie przynoszą oczekiwanych rezultatów. W konsekwencji problemy wywołane przez kryzys pozostają nierozwiązane. Brak możliwości rozwiązania problemów, nieefektywne metody radzenia sobie w trudnej sytuacji sprzyjają rozwojowi fazy czwartej, w której może dochodzić do rozwoju nieadaptacyjnych zachowań lub zaburzeń psychicznych $(\mathrm{Ca}-$ plan, 1964).

Metodą wywodzącą się z teorii Caplana jest interwencja kryzysowa (Heszen-Niejodek, 2002). Polega ona na doraźnym, krótkoterminowym oddziaływaniu, które zmierza do udzielenia natychmiastowej pomocy osobom doświadczającym kryzysu psychicznego (Korzeniowski, Pużyński, 1986). Wzorcowy model takiej interwencji polega na zapewnieniu wsparcia emocjonalnego i poczucia bezpieczeństwa oraz redukcji lęku przez analizę sytuacji powodującej kryzys, rozpoznanie dotychczas stosowanych strategii, nauczenie i wdrożenie nowych. Interwencja kryzysowa, przywracając utraconą równowagę, podkreśla znaczenie empatii oraz praktycznych odpowiedzi na potrzeby utrzymania zasobów psychologicznych jednostki (Kubacka-Jasiecka, 2010).

W wielu przypadkach długotrwałe, wykraczające poza sytuację kryzysową odczuwanie napięcia dezorganizuje normalne funkcjonowanie jednostki i wymaga pomocy psychologa lub psychiatry innej niż doraźna, interwencyjna. Współczesne leczenie psychiatryczne najczęściej łączy różnorodne metody oddziaływania. Powszechną praktyką jest uzupełnianie leczenia farmakologicznego psychoterapią. Warto zauważyć, że tendencja ta zależna jest od wiedzy na temat metod psychoterapeutycznych wśród lekarzy psychiatrów. Wykazywano, że odbywanie szkoleń psychoterapeutycznych, poszerzanie wiedzy o dostępnych metodach zwiększa odsetek skierowań na psychoterapię przed rozpoczęciem leczenia farmakologicznego pacjentów psychiatrycznych (Murawiec i in., 2019). Wykazywano również, że właśnie psychoterapia jest jedną z bardziej efektywnych metod leczenia. Wyniki badań dowiodły, że psychoterapia - stosowana zarówno samodzielnie, jak i w połączeniu $\mathrm{z}$ farmakoterapią - jest skuteczniejsza niż placebo oraz że w wielu przypadkach psychoterapia jest przynajmniej tak samo skuteczna jak leczenie farmakologiczne. Warto podkreślić, że korzystne efekty oddziaływania leków są również podtrzymywane przez skuteczną psychoterapię (Huhn i in., 2014; Kalita, Chrzan-Dętkoś, 2018; Lipsey, Wilson, 1993).

\section{MODEL ŚRODOWISKOWY}

Ograniczony dostęp do świadczeń zdrowotnych z zakresu zdrowia psychicznego, w tym do psychoterapii, jest istotnym problemem zarówno w Polsce, jak i na świecie. Jednym z zadań WHO w tym obszarze na lata 2013-2020 jest „zapewnienie spójnych, zintegrowanych i dostępnych usług z zakresu zdrowia psychicznego w społecznościach lokalnych" (WHO, 2001). Rekomendacje autorów polskiego badania epidemiologicznego oceniającego rozpowszechnienie zaburzeń psychicznych (Kiejna i in., 2015) wskazują na konieczność rozwoju systemu ochrony zdrowia psychicznego w kierunku modeli opieki środowiskowej, obejmującej zarówno świadczenia w ramach podstawowej i specjalistycznej opieki zdrowotnej, jak i opiekę społeczną oraz poradnictwo psychologiczno-pedagogiczne. Model środowiskowy uwzględnia również współpracę organizacji pozarządowych. W ramach tej współpracy byłyby tworzone sieci wsparcia promujące zdrowie psychiczne. Istotne jest, aby w sferze 
organizacji usług środowiskowych wykorzystywać zasoby dostępne lokalnie (instytucje i kapitał ludzki). W zakresie udzielanego wsparcia diagnozuje się ponadto zasoby systemu rodzinnego - dorosłego, jak i dziecka - pod kątem jego potencjału. Jest to punkt wyjścia do organizacji planów zdrowienia, tak aby w proces leczenia włączyć wszystkie możliwe i ważne zasoby obecne w środowisku.

$\mathrm{Z}$ doświadczeń i praktyki klinicystów wynika, że rozwijanie środowiskowej opieki psychiatrycznej, wraz ze wspólistniejącym efektywnym oparciem społecznym, zmniejsza zapotrzebowanie na opiekę stacjonarną, która zazwyczaj przekształca się w kierunku wysokospecjalistycznym, przeznaczonym dla bardzo ciężkich i złożonych przypadków zaburzeń psychicznych. W Polsce już od lat 80. XX w. podejmowano inspirowane myślą Antoniego Kępińskiego próby ulepszenia modelu leczenia i rehabilitacji przez integrację osoby chorującej na schizofrenię i jej rodziny we wspólnej przestrzeni życia (Cechnicki, 2009; Kępiński, 2013). W ostatnich latach rozwój opieki środowiskowej staje się ważnym aspektem polityki zdrowotnej - tak w przypadku organizacji ochrony zdrowia, jak i w koordynacji międzysektorowej (Meder, Jarema, Araszkiewicz, 2008). Wzmacniającymi ten kierunek są dwa programy: reforma w psychiatrii dzieci i młodzieży oraz pilotaż Centrum Zdrowia Psychicznego. Stanowią one pochodną Narodowego Programu Ochrony Zdrowia Psychicznego na lata 2017-2022. Oba programy zostały uruchomione w 2019 r. i wiążą się z dużo większymi nakładami na usługi środowiskowe. Zorientowanie na potrzeby osoby chorującej, indywidualny program terapeutyczny, dostępny zarówno dla pacjenta, jak i jego rodziny, są podstawowymi założeniami opieki środowiskowej (Meder i in., 2008). Dzisiaj te założenia są wcielane w życie w tworzonych Środowiskowych Centrach Zdrowia Psychicznego, których podstawą jest metoda Otwartego Dialogu. Wydaje się, że ten sposób wspierania osób w kryzysach psychicznych jest najbardziej adekwatny do opieki środowiskowej, gdyż pozwala $\mathrm{w}$ sposób uporządkowany włączać w proces zdrowienia zasoby rodziny i najbliższego otoczenia dziecka lub dorosłego.

\section{OTWARTY DIALOG}

Metoda Otwartego Dialogu (Open Dialogue approach - ODA), stosowana w terapii zaburzeń psychicznych, jest wynikiem wieloletnich doświadczeń Jaakka Seikkuli (psychoterapeuty, psychologa klinicznego) i Birgitty Alakare (psychiatry) oraz członków ich zespołu ze szpitala Keropudas w Finlandii (Seikkula, Arnkil, 2018a, 2018b). Od lat 80. XX w. jest ciągle stosowana i rozwijana i budzi coraz większe zainteresowanie. Aktualnie prowadzone są całościowe kursy ze stosowania terapii ODA w leczeniu. Metoda bazuje na podejściu dostosowanym do potrzeb, opracowanym w latach 60. XX w. przez Yrjö Alanena i jego zespół (stosował je wówczas w leczeniu schizofrenii). Zakłada ona szybką interwencję we wczesnej fazie kryzysu psychicznego, postrzeganie leczenia jako procesu wykorzystującego różne metody terapeutyczne, zasoby indywidualne i rodzinne oraz dostosowanie do indywidualnych potrzeb pacjenta i jego bliskich. Twórcy metody podkreślają, że niezwykle istotne $\mathrm{w}$ procesie leczniczym są relacje pacjenta $\mathrm{w}$ jego naturalnym środowisku. Akcentują zatem odbudowę i poprawę tychże relacji społecznych. Podstawą tego podejścia jest współodpowiedzialność, podmiotowość i relacje interpersonalne pacjenta (Lakeman, 2014; Seikkula, Alakare, 2012).

Nazwa otwarty dialog została użyta po raz pierwszy w 1995 r. do opisu terapii skoncentrowanej na rodzinie oraz sieci społecznej pacjenta (Seikkula i in., 1995). Autorzy metody podkreślają, że dialog stanowi najbardziej podstawową i naturalną potrzebę człowieka. Za podstawę metody przyjęto otwarte spotkania terapeutyczne, w których uczestniczą, poza samą osobą w kryzysie, wszystkie osoby jej bliskie i dla niej ważne oraz moderujący spotkanie profesjonaliści (Krawczyk, Solarz, Wciórka, 2015; Seikkula, Arnkil, 2018a). 
Niejednokrotnie wykazywano, że wsparcie emocjonalne najbliższego otoczenia zwiększa zdolność do radzenia sobie w trudnych sytuacjach. Wzrost poczucia wartości, potwierdzenie własnej skuteczności oraz poczucie bezpieczeństwa zapewniane przez rodzinę gwarantuje sprzyjające warunki do rozwoju umiejętności neutralizowania oddziaływań sytuacji stresogennych (van Harmelen i in., 2016).

Nurt narracyjny, zaczerpnięty wprost $z$ terapii systemowej, stanowi jeden $z$ elementów koncepcji ODA. Należy jednak podkreślić, że w swoich założeniach ODA to nie tylko metoda terapii - charakteryzuje ją innowacyjne, wielowymiarowe podejście skoncentrowane na wykorzystaniu zasobów środowiska osób dotkniętych kryzysem psychicznym. Podstawę ODA tworzy koncepcja terapii zorientowanej na potrzeby (need adapted treatment - NATM; Alanen, 2000; Seikkula, Arnkil, 2018b). Koncepcja ta, podobna do koncepcji opracowanych w ramach konstrukcjonizmu społecznego, zakłada, że problem jest uwarunkowany społecznie i ma swoistą naturę językową. To pacjent określa problem, terapeuta nie ma możliwości wyręczenia go w tym. Konstrukcjonizm społeczny i ODA mają spójne podejście $\mathrm{w}$ widzeniu problemu - $\mathrm{w}$ ich perspektywie problemy nie istnieją poza narracją, będącą systemem nadawania znaczeń. Analogiczne sytuacje przez jednych będą odbierane jako problem, przez innych zaś nie, w zależności od indywidualnego języka, którym są opisywane. W ramach ODA postulowano nawet, aby terapeuta przyjmowal postawę „niewidzenia” (not-knowing stance), która wyklucza uprzednie przyjmowanie perspektywy innej niż perspektywa pacjenta (Błądziński, Cechnicki, Bogacz, Cichocki, 2014). Postawa ta umożliwia wsłuchanie się w to, co mówią pacjenci. Podstawowe znaczenie w terapii ma więc rozwijanie i podtrzymywanie dialogu, co sprzyja powstawaniu nowych opisów sytuacji, a tym samym odnajdywaniu innych, nowych słów takiego opisu i w konsekwencji zrozumieniu i rozwiązaniu problemu (Anderson, 2007).

Metoda Otwartego Dialogu, a właściwie jej skuteczne wykorzystanie wymaga zastosowania siedmiu zasad:

Natychmiastowa pomoc (1) - pierwsze spotkanie terapeutyczne odbywa się w ciągu pierwszej doby od wystąpienia kryzysu. Celem natychmiastowego nawiązania kontaktu jest przede wszystkim uniknięcie hospitalizacji. Pacjent ma możliwość opowiedzenia o swoich doświadczeniach, często bagatelizowanych przez bliskich. Poczucie bezpieczeństwa zapewnia bezpieczną przestrzeń dla wyrażenia swoich obaw. Zaproszenie do spotkań najbliższej rodziny i ważnych dla pacjenta osób, czyli wtaczenie sieci spotecznej (2), tworzy dodatkowe wsparcie oraz, dzięki dostrzeżeniu różnych perspektyw, pomaga zdefiniować problem. Dostosowanie leczenia i terapii do zmieniających się potrzeb pacjenta i jego rodziny, a także realizowanie terapii w naturalnym środowisku pacjenta - w jego domu - stanowi o elastyczności i mobilności (3) metody. Możliwość odbywania terapii w domu zapewnia bezpieczeństwo i poczucie większej skuteczności ze względu na dostępność wszystkich zasobów rodziny. Metoda Otwartego Dialogu zakłada, że pacjent otrzymuje pomoc od zespołu specjalistów, którzy $\mathrm{w}$ przypadku rozbieżności opinii wspólnie z pacjentem podejmują decyzję (shared decision making - SDM) oraz zapewniają komplementarne działania terapeutyczne. Odpowiedzialnośc (4) za zapewnienie rodziny o otrzymaniu pomocy oraz za zorganizowanie spotkania spoczywa na osobie, z którą nawiązano pierwszy kontakt. Zespół terapeutyczny odpowiada za zapewnienie ciagtości psychologicznej (5). Odpowiedzialność zespołu za cały proces leczenia, niezależnie od czasu jego trwania, ogranicza ryzyko zmiany terapeutów i przeniesienia uwagi z procesu leczenia na podejmowanie szybkich działań. Regularne spotkania z pacjentami w kryzysie budują poczucie bezpieczeństwa dające możliwość swobodnego rozmawiania o trudnych, przytłaczających doświadczeniach. Wspieranie umiejętności słuchania siebie nawzajem oraz koncentracja na rozmowie, a nie na chorobie, jest wyrazem tolerancji niepewności (6). W założeniach metody podkreśla się, że największą jej zaletą jest odzyskanie przez pacjenta kontroli nad swoim życiem dzięki otwartemu mówieniu o problemie. 
Dialogowośc (7) oraz moderowanie rozmów w grupie społecznej pacjenta należą do zadań terapeutów (Seikkula, Arnkil, 2018b, 2018a).

Terapeuci pracujący w podejściu ODA koncentrują swoje wysiłki na moderowaniu dialogu między zespołem terapeutycznym, pacjentem i jego siecią wsparcia społecznego. Podkreśla się też znaczenie słuchania i adekwatnego reagowania na wypowiedzi. Seikkula (Seikkula, Arnkil, 2018a) zaznacza, że aktywne słuchanie jest nawet ważniejsze niż sama interwencja lub terapeutyczna interpretacja monologów pacjentów. Dostosowanie podejścia terapeutycznego do zmieniających się potrzeb jednostek i ich rodzin oraz włączenie terapii i interwencji rodzinnej w sytuacji doświadczenia kryzysu sprawiają, że metoda zyskuje coraz większe uznanie (Lakeman, 2014).

Uwzględnienie perspektywy środowiska - rodziny, szkoły czy pracy - oraz pierwsze dane dotyczące efektywności metody (Aaltonen, Seikkula, Lehtinen, 2011; Bergström i in., 2017, 2018; Freeman, Tribe, Stott, Pilling, 2019; Gromer-Thomas, 2012; Seikkula, Alakare, Aaltonen, 2001; Seikkula i in., 2003, 2006) są obiecujące. Krytyczny przegląd danych wskazuje jednak na brak spójności i błędy metodologiczne, które nie pozwalają na generalizację wyników (Freeman i in., 2019). Badanie efektywności ODA napotyka typowe problemy w pomiarach skuteczności metod psychoterapeutycznych. Wydaje się, że dotychczasowe badania wymagają bardziej usystematyzowanych i jasno zdefiniowanych metod naukowych (choćby jasnego kanonu metod jakościowych i ilościowych). Może to być proces bardziej złożony niż w klasycznych badaniach kwestionariuszowych, ponieważ efekt tej metody z samego założenia zależy od bardzo wielu czynników. Trudno też tutaj o sensowny redukcjonizm empiryczny bez utraty istoty procesu psychoterapeutycznego (np. zasoby i bariery w środowisku lub zależności systemowe między rodziną, dzieckiem czy szkołą). Kolejnym czynnikiem mogącym istotnie wpływać na wyniki są kwalifikacje specjalistów (tzw. fidelity criteria). Specjaliści mogą sądzić, że stosują ODA, jednak najczęściej są po różnych szkołach, o różnym czasie trwania (jednorocznych, dwuletnich czy po całościowych szkoleniach czteroletnich). Projekt https://www.hopendialogue.net/ jest pierwszym badaniem międzynarodowym, uwzględniającym fidelity criteria w ocenie efektywności ODA w różnych krajach.

Badania nad nową metodą są wstępnie obiecujące, pomimo głosów krytycznych. Otwarty Dialog jest spójny z założeniami deinstytucjonalizacji, budowania sieci wsparcia w lokalnym środowisku $\mathrm{z}$ wykorzystaniem istniejących w nim zasobów. Promując oddziaływania psychospołeczne i terapeutyczne, badacze opowiadają się za założeniami ODA, w której farmakoterapia nie jest metoda pierwszego wyboru. Jak wskazują Lakeman i Whitaker (Lakeman, 2014; Whitaker, 2010), zastosowanie ODA przez dwa lata umożliwiało powrót do życia zawodowego aż $84 \%$ pacjentów po pierwszym epizodzie psychozy. Wykazano też, że u $67 \%$ pacjentów nie występował nawrót objawów psychotycznych w ciągu pięciu lat obserwacji (Thomas, 2011).

Badacze podkreślają również, że pozytywne oddziaływanie ODA dodatkowo wpływa na wzrost jakości życia oraz obniża śmiertelność (w efekcie ograniczenia wpływu działań ubocznych stosowanych wcześniej leków przeciwpsychotycznych; Waterreus i in., 2012; Weinmann, Read, Aderhold, 2009).

Przeobrażenie klasycznej opieki psychiatrycznej w Finlandii na rzecz kompleksowej opieki środowiskowej przyniosło wymierne rezultaty - innowacyjny model okazał się na tyle skuteczny, że liczba i długość hospitalizacji w szpitalach/na oddziałach psychiatrycznych zmalały bez konieczności wieloletniej farmakoterapii (Bergström i in., 2018; Kłapciński, Rymaszewska, 2015; Seikkula, Arnkil, 2018b; Seikkula i in., 2006). Pacjenci objęci programem ODA częściej wracali do pracy oraz podejmowali aktywność edukacyjną - byli w stanie rozpocząć nowe studia lub wrócić na dotychczasowe. Na podstawie pięcioletniej obserwacji Seikkula (Seikkula i in., 2006) wykazał, że 86\% pacjentów podjęło aktywność zawodową lub aktywnie poszukiwało pracy. 
Kamieniem milowym w rozwoju stosowania ODA była realizacja Fińskiego Narodowego Programu Leczenia Schizofrenii 1981-1987 (Pylkkänen, 2011; Tuori i in., 1998). Dziesięcioletnia ewaluacja rezultatów projektu wykazała, że interwencja psychosocjalna obniżyła zapotrzebowanie na hospitalizację o $60 \%$, a w $68 \%$ przypadków skróciła czas pobytu pacjentów w szpitalach psychiatrycznych (Lehtinen, Taipale, 2001; Tuori i in., 1998). Podobne projekty realizowane były w innych krajach skandynawskich - szwedzki Parachute Project również wykazał, że terapia dostosowana do potrzeb, skoncentrowana na aspektach psychosocjalnych, znacząco zredukowała potrzebę stosowania neuroleptyków (Cullberg i in., 2002, 2006).

Sukces, jaki metoda odniosła w Finlandii, wzbudził chęć jej wdrożenia do systemów opieki psychiatrycznej w innych państwach. Duże zainteresowanie wykazywano m.in. w Wielkiej Brytanii i Stanach Zjednoczonych (Buus i in., 2017, 2019; Gordon, Gidugu, Rogers, DeRonck, Ziedonis, 2016; Olson, Seikkula,Ziedonis, 2014; Razzaque, Wood, 2015; Tribe, Freeman, Livingstone, Stott, Pilling, 2019). Klinicyści podkreślają, że innowacyjność metody polega na tolerancji niepewności, która stanowi zaprzeczenie podejścia skoncentrowanego na chorobie (Razzaque, Wood, 2015). Rozmowy budują poczucie bezpieczeństwa, mobilizują zasoby pacjenta oraz jego rodziny. Wydaje się więc, że tolerancja niepewności zapewnia im czas na zrozumienie istoty problemu i znalezienie rozwiązań, które przez szybsze podejmowanie decyzji mogłyby zostać przedwcześnie wykluczone (Gordon i in., 2016). Pomimo niezaprzeczalnych korzyści to właśnie ten element przysparza klinicystom najwięcej trudności. Podkreślają, że do rozwijania tej metody terapeutycznej niezbędne są właściwe szkolenia, warsztaty i treningi z doświadczonymi terapeutami (Jones, 2019).

Dostępne dane literaturowe potwierdzają fakt nieustannego zainteresowania klinicystów zastosowaniem i doskonaleniem ODA. W środowiskach terapeutycznych, m.in. w Stanach Zjednoczonych oraz Wielkiej Brytanii, rozpoczęto szkolenia pracowników służby zdrowia mające na celu poszerzenie sieci wsparcia społecznego pacjentów (Razzaque, Stockmann, 2016; Stockmann i in., 2019). Budowanie grup wzajemnego wsparcia przez osoby, które również wcześniej doświadczały kryzysu i otrzymywały pomoc ze strony środowisk medycznych, podnosi zaufanie chorych do zespołów terapeutycznych. Pomoc grupy jest szczególnie istotna, jeśli pacjent nie ma wystarczającego wsparcia w swoim otoczeniu (Razzaque, Stockmann, 2016). Klinicyści podkreślają, że rozszerzanie kompetencji zespołów terapeutycznych o grupy wsparcia pozwala wspierać rozwój osobowości, rozwijać nowe umiejętności oraz zapobiegać wypaleniu zawodowemu terapeutów. Grupa wsparcia sprzyja wzrostowi pewności oraz niezależności pacjenta, wyklucza jego społeczną izolację, a to przekłada się na poprawę jakości życia. Grupy wsparcia w placówkach realizujących świadczenia terapeutyczne zwiększają wzajemną świadomość problemów pacjentów oraz umiejętności komunikacyjne między członkami zespołów terapeutycznych, a tym samym ich skuteczność (Repper, Carter, 2011). Pracujący na oddziałach psychiatrycznych klinicyści chętnie implementujący ODA podkreślają też, że wartość, jaką niosą ze sobą wprowadzane zmiany, czyli zwiększenie skuteczności metod terapeutycznych, nie indukuje żadnych dodatkowych kosztów (Rosen, Stoklosa, 2016).

Implementacja ODA przysparzała klinicystom obaw co do zakresu ich umiejętności. Nie mieli także pewności, czy wdrożenie nowego podejścia terapeutycznego spełni oczekiwania pacjentów przyzwyczajonych do dotychczasowych rozwiązań (Mairs, Bradshaw, 2005). Podjęcie działań innych niż nawykowe i zautomatyzowane było wyzwaniem również dla klinicystów, wprowadzenie innowacyjnej metody oznacza bowiem budowanie odmiennej relacji z pacjentem oraz wydłużenie czasu interwencji. Uwzględnienie relacji z najbliższym otoczeniem osoby w kryzysie czy z zaburzeniami psychicznymi sprawia, że oddziaływanie terapeutyczne jest bardziej złożone (Kavanagh, 2016). W Wielkiej Brytanii przeprowadzono badania ankietowe wśród beneficjentów ODA oraz klinicystów (Razzaque, Wood, 2015). Wykazano, że w celu uzyskania właściwych efektów tej metody potrzebne są określone, 
specyficzne dla niej procedury. Niektórzy podkreślali, że jest to wręcz niezbędny element, który sprzyja zaangażowaniu terapeutów i daje poczucie bezpieczeństwa pacjentom. Dla niektórych pacjentów poczucie braku jasno określonego celu spotkania terapeutycznego (w porównaniu z wcześniejszymi doświadczeniami) było bowiem przyczyną dodatkowego stresu.

Zdystansowanie społeczne oraz obawy terapeutów względem ODA nie odwiodło jednak klinicystów od jej stosowania i oceny możliwości implementacji w innych populacjach (Freeman i in., 2019; Razzaque, Wood, 2015). Należy zauważyć, że wraz z coraz szerszym zastosowaniem ODA wielu początkowo sceptycznych terapeutów zmieniło zdanie co do jej skuteczności. Podkreślali, że metoda pozytywnie wpływa na jakość kontaktu terapeutycznego, co przekłada się na zadowolenie pacjentów z opieki (Stockmann i in., 2019; Tribe i in., 2019). Autentyczność relacji z pacjentem, możliwość swobodnych rozmów i ekspresji emocji stanowi według terapeutów największą zaletę ODA (Tribe i in., 2019).

\section{OTWARTY DIALOG W POLSCE}

Prekursorem Metody Otwartego Dialogu była Fundacja Polski Instytut Otwartego Dialogu. Celem działalności Fundacji jest aktywne wspieranie w procesie zdrowienia osób doświadczających trudności w zakresie zdrowia psychicznego. Wzorując się na doświadczeniach psychiatrów oraz psychoterapeutów z Finlandii, Fundacja podjęła międzynarodową współpracę, której efektem była inicjacja przeniesienia rozwiązań terapeutycznych na grunt polski. Facylitatorzy procesu zmian w systemie zdrowia psychicznego i pomocy społecznej w Polsce podkreślają, że celem metody jest zapewnienie uczestnikom spotkań terapeutycznych i możliwości bycia wysłuchanym. Założenie to umożliwia terapeutom pracującym w środowisku osoby doświadczającej kryzysu skoncentrowanie się nie tylko na odnalezieniu porozumienia, lecz także na odbudowaniu relacji, które dotychczas nie gwarantowały bezpiecznej przestrzeni na rozwój.

\section{OTWARTY DIALOG I ŚRODOWISKOWE CENTRA ZDROWIA PSYCHICZNEGO}

Doświadczenia krajów Europy Zachodniej pokazują, że skuteczna pomoc osobom z nawet poważnymi zaburzeniami psychicznymi może odbywać się $w$ ich naturalnym środowisku. Wynika z tego, że opieka psychiatryczna jest wówczas równie efektywna, nawet jeśli odbiega od tradycyjnego leczenia dolegliwości somatycznych, unikając hospitalizacji już w założeniach organizacyjnych (Kochański, 2016). Badania, które uwzględniały proces przekształcania opieki psychiatrycznej w opiekę środowiskową, wykazują korzystny wpływ takich zmian na proces zdrowienia osoby dotkniętej zaburzeniem/kryzysem psychicznym. Podkreślają także innowacyjność modelu opieki, w którym nadrzędnym elementem jest utożsamianie systemu opieki z najbliższą społecznością pacjenta (Mezzina, 2014).

Rozwiązania opieki psychiatrycznej na świecie nie są jednolite, niemniej jednak wszystkie podkreślają znaczenie opieki środowiskowej. W ostatnich latach, na podstawie raportów WHO, w ramach reformy systemu opieki psychiatrycznej w Belgii odchodzi się od dużych centrów na rzecz działań podejmowanych na szczeblu lokalnym, tworzenia mniejszych ośrodków oraz mobilnych zespołów. Zespół specjalistów świadczy pomoc psychologiczną i psychiatryczną osobom, które według dawnego systemu kwalifikowałyby się do hospitalizacji.

W Szwecji osoby z zaburzeniami psychicznymi mogą uzyskać wsparcie asystenta, który pomaga w codziennym funkcjonowaniu, bądź mogą otrzymać zakwaterowanie $\mathrm{w}$ domu z całodobową opieką specjalistów. Osoby doświadczające kryzysu mają także możliwość podjęcia pracy chronionej. 
Podobną droga podąża Polska, gdzie w ostatnich latach powstały Środowiskowe Centra Zdrowia Psychicznego, szczególnie dla dzieci i młodzieży (Lenkiewicz, 2020). Ośrodki te oferują opiekę specjalistów, angażują zespoły mobilne, a także zapewniają fizyczne włączenie osób doświadczających kryzysów psychicznych w lokalne społeczności, tym samym nie ograniczając zdolności oraz gotowości osób do pełnego uczestnictwa w życiu ogólnie pojętego społeczeństwa. Utworzeniu zarówno Środowiskowych Centrów Zdrowia Psychicznego, jak i ODA przyświeca idea leczenia z wykorzystaniem zasobów najbliższego otoczenia. Oba te podmioty podkreślają znaczenie leczenia środowiskowego i wzajemnie się uzupełniają. Środowiskowe Centra Zdrowia Psychicznego zakładają odejście od modelu azylowego, izolowania chorego, na rzecz podejmowania zintegrowanych działań z zakresu usług medycznych, społecznych i edukacyjnych w celu włączenia osoby doświadczającej kryzysu psychicznego w życie lokalnej społeczności. Idea ta koncentruje się na wykorzystaniu wszystkich możliwych zasobów pacjenta i jego rodziny w celu zapobiegania wykluczeniu osoby w kryzysie z życia społecznego, zawodowego. Aktywne funkcjonowanie w społeczeństwie, podejmowanie aktywności zawodowych traktowane jest jako najlepszy sposób rehabilitacji (Kłapciński, Rymaszewska, 2015). Potrzeba wdrożenia oddziaływań psychospołecznych, podejmowania zintegrowanych działań z zakresu usług medycznych, społecznych i edukacyjnych, a także refleksja nad dotychczasowym modelem terapeutycznym skłoniła terapeutów do utworzenia Środowiskowych Centrów Zdrowia Psychicznego. Jednostki te dzięki ODA realizują działania, które osobom w kryzysie psychicznym pomagają wrócić do codziennych obowiązków i relacji rodzinnych. Dzięki podejściu holistycznemu zespół terapeutyczny ma możliwość nie tylko zweryfikowania założeń, ale również sformułowania rekomendacji systemowych dotyczących opieki psychiatrycznej w Polsce.

Człowiek w procesie zdrowienia intuicyjnie szuka rozwiązań odpowiadających jego potrzebie rozwoju, dążąc tym samym do pełnego i świadomego uczestnictwa w życiu społecznym. Gdy osoby doświadczone kryzysem psychicznym są wspóltwórcami rozwiązań własnych problemów, rozwiązania te naturalnie wzmacniają proces zdrowienia. Wszelkie propozycje pomocy kierowane do chorych muszą uwzględniać głos samych potrzebujących. U podstaw Środowiskowych Centrów Zdrowia Psychicznego leży przekonanie, że to właśnie dialog odgrywa funkcję terapeutyczną i jednocześnie „zdejmuje (stygmatyzującą) klątwę" zawartą w diagnozie psychiatrycznej. Budowa systemu ochrony zdrowia psychicznego nie zostanie zrealizowana bez perspektywy osobistego doświadczania kryzysu oraz procesu zdrowienia. Perspektywa ta wnosi niezwykle cenne informacje i ujawnia potrzeby, które trudno jest dostrzec $z$ punktu widzenia osób pomagających profesjonalnie.

\section{PODSUMOWANIE}

$\mathrm{Na}$ podstawie dostępnych doniesień literaturowych należy uznać, że Otwarty Dialog jest sprawdzoną metodą terapeutyczną, wymaga jednak odpowiednio przeszkolonego i licznego personelu oraz dobrej organizacji systemów opieki zdrowotnej. Sposoby rozwiązywania problemów zdrowia psychicznego, możliwość uzyskania wczesnej interwencji, zaangażowanie zespołów terapeutycznych, a także przełamanie stereotypu dotyczącego gwarancji efektywności leczenia jedynie w szpitalu stanowią zakres odpowiedzialności lokalnej społeczności. Hospitalizacja w niektórych przypadkach bywa oczywiście nieunikniona, jednak założenia Otwartego Dialogu uwzględniają dążenie do tego, aby pobyt w placówce trwał jak najkrócej. Doświadczenia klinicystów z innych krajów wskazują, że zasadne jest podejmowanie leczenia $\mathrm{w}$ środowisku chorego, leczenia angażującego możliwie najszerszą dostępną sieć społeczną, ponieważ jak najszybsze podjęcie terapii w naturalnym środowisku niweluje ryzyko utraty roli społecznej pacjenta (Krawczyk i in., 2015). 
Wykorzystywanie ODA w Środowiskowych Centrach Zdrowia Psychicznego gwarantuje, że świadczona pomoc jest adekwatną odpowiedzią na potrzeby osób doświadczających kryzysu psychicznego. Komplementarność założeń takich jak rozbudowanie sieci pomocy przez włączenie instytucji zewnętrznych, współpracujących w środowisku lokalnym (ośrodki interwencji kryzysowej, zespoły mobilne, poradnie), oraz udzielanie natychmiastowej pomocy sprzyja rozwojowi modeli pomocy psychiatrycznej opartych na szerokim rozumieniu kryzysów psychicznych.

Szansa na skuteczność zarówno ODA, jak i Środowiskowych Centrów Zdrowia Psychicznego tworzonych w Polsce wydaje się wysoka. Na razie jednak pozostaje jedynie szansą. Potrzebne są szeroko zakrojone badania skuteczności wprowadzonych zmian, zarówno w zakresie indywidualnego polepszenia funkcjonowania i jakości życia osób z zaburzeniami lub w kryzysie, społecznego odbioru i funkcjonowania tych zmian, jak i ich społecznych i ekonomicznych konsekwencji. Badania naukowe tego dotyczące wydają się koniecznym następnym krokiem.

\section{BIBLIOGRAFIA}

Aaltonen, J., Seikkula, J., Lehtinen, K. (2011). The comprehensive Open-Dialogue approach in Western Lapland: I. The incidence of non-affective psychosis and prodromal states. Psychosis, 3, 179-191. https://doi.org/10.1080/17522439.2011.601750

Alanen, Y. 0. (2000). Schizofrenia. Jej przyczyny i leczenie dostosowane do potrzeb. Warszawa: Instytut Psychiatrii i Neurologii.

Anderson, H. (2007). The heart and spirit of collaborative therapy: The philosophical stance - „A way of being” in relationship and conversation. W: H. Anderson, D. Gehart (red.), Collaborative therapy: relationships and conversations that make a difference (s. 43-59). Nowy Jork: Routledge.

Bergström, T., Alakare, B., Aaltonen, J., Mäki, P., Köngäs-Saviaro, P., Taskila,J.J., Seikkula,J. (2017). The long-term use of psychiatric services within the Open Dialogue treatment system after first-episode psychosis. Psychosis, 9(4), 310-321. https://doi.org/10.1080/17522439.2017.1344295

Bergström, T., Seikkula, J., Alakare, B., Mäki, P., Köngäs-Saviaro, P., Taskila, J. J., ... Aaltonen, J. (2018). The family-oriented Open Dialogue approach in the treatment of first-episode psychosis: nineteen-year outcomes. Psychiatry Research, 270, 168-175. https://doi.org/10.1016/j. psychres.2018.09.039

Błądziński, P., Cechnicki, A., Bogacz, J., Cichocki, Ł. (2014). Znaczenie Otwartego Dialogu w leczeniu osób chorujących na schizofrenię. Postępy Psychiatrii i Neurologii, 23, 134-139. https://doi.org/10.1016/j.pin.2014.06.004

Buus, N., Bikic, A., Kragh Jacobsen, E., Müller-Nielsen, K., Aagaard, J., Rossen, C. B. (2017). Adapting and implementing Open Dialogue in the Scandinavian countries: a scoping review. Issues in Mental Health Nursing, 38, 391-401. https://doi.org/10.1080/01612840.2016.1269377

Buus, N., Kragh Jacobsen, E., Bojesen, A. B., Bikic, A., Müller-Nielsen, K., Aagaard, J., Erlangsen, A. (2019). The association between Open Dialogue to young Danes in acute psychiatric crisis and their use of health care and social services: a retrospective register-based cohort study. International Journal of Nursing Studies, 91, 119-127. https://doi.org/10.1016/j.jinurstu.2018.12.015

Caplan, G. (1964). Principles of preventive psychiatry. Londyn: Tavistock.

Cechnicki, A. (2009). W stronę psychoterapeutycznie zorientowanej psychiatrii środowiskowej - 30 lat doświadczeń krakowskich. Pro memoriam Professor Antoni Kępiński. Psychoterapia, 3(150), 43-55.

Cullberg, J., Levander, S., Holmqvist, R., Mattsson, M., Wieselgren, I.-M. (2002). One-year outcome in first episode psychosis patients in the Swedish Parachute project. Acta Psychiatrica Scandinavica, 106, 276-285. https://doi.org/10.1034/j.1600-0447.2002.02376.x

Cullberg, J., Mattsson, M., Levander, S., Holmqvist, R., Tomsmark, L., Elingfors, C., Wieselgren, I.-M. (2006). Treatment costs and clinical outcome for first episode schizophrenia patients: a 3-year follow-up of the Swedish "Parachute Project" and two comparison groups. Acta Psychiatrica Scandinavica, 114, 274-281. https://doi.org/10.1111/j.1600-0447.2006.00788.x

Dieterich, M., Irving, C. B., Bergman, H., Khokhar, M. A., Park, B., Marshall, M. (2017). Intensive case management for severe mental illness. Schizophrenia Bulletin, 43, 698-700. https://doi.org/10.1093/schbul/sbx061

Felgoise, S., Nezu, A. M., Nezu, C. M., Reinecke, M. A. (red.). (2005). Encyclopedia of cognitive behavior therapy. Heidelberg: Springer.

Freeman, A. M., Tribe, R. H., Stott, J. C. H., Pilling, S. (2019). Open Dialogue: a review of the evidence. Psychiatric Services, 70, 46-59. https://doi. org/10.1176/appi.ps.201800236

Goldman, P. S., Bakermans-Kranenburg, M. J., Bradford, B., Christopoulos, A., Ken, P. L. A., Cuthbert, C., .. Sonuga-Barke, E. J. S. (2020). Institutionalisation and deinstitutionalisation of children 2: policy and practice recommendations for global, national, and local actors. The Lancet Child and Adolescent Health, 4, 606-633. https://doi.org/10.1016/52352-4642(20)30060-2

Gordon, C., Gidugu, V., Rogers, E. S., DeRonck, J., Ziedonis, D. (2016). Adapting Open Dialogue for early-onset psychosis into the U.S. health care environment: a feasibility study. Psychiatric Services, 67, 1166-1168. https://doi.org/10.1176/appi.ps.201600271 
Gromer-Thomas, J. (2012). Need-adapted and Open-Dialogue treatments: empirically supported psychosocial interventions for schizophrenia and other psychotic disorders. Ethical Human Psychology and Psychiatry, 14, 162-177. https://doi.org/10.1891/1559-4343.14.3.162

Heszen-Niejodek, I. (red.). (2002). Teoretyczne i kliniczne problemy radzenia sobie ze stresem. Poznań: Stowarzyszenie Psychologia i Architektura.

Huhn, M., Tardy, M., Spineli, L. M., Kissling, W., Förstl, H., Pitschel-Walz, G., .. Leucht, S. (2014). Efficacy of pharmacotherapy and psychotherapy for adult psychiatric disorders: a systematic overview of meta-analyses. JAMA Psychiatry, 71, 706-715. https://doi.org/10.1001/jamapsychiatry.2014.112

IJzendoorn, M. H. van, Bakermans-Kranenburg, M. J., Duschinsky, R., Fox, N. A., Goldman, P. S., Gunnar, M. R., .. Sonuga-Barke, E. J. S. (2020). Institutionalisation and deinstitutionalisation of children 1: a systematic and integrative review of evidence regarding effects on development. The Lancet Psychiatry, 7, 703-720. https://doi.org/10.1016/\$2215-0366(19)30399-2

Jones, T. M. (2019). Nurses experiences on using open dialogue approach in a local mental health service: An interpretative phenomenological analysis (rozprawa doktorska, School of Healthcare Sciences Cardiff University). Pobrane z: https://orca.cardiff.ac.uk/130876/19/CM20002637 - Doctor of Advanced Healthcare Practice - Thesis - FINAL for....pdf

Kalita, L., Chrzan-Dętkoś, M. (2018). Program stażowy jako skuteczne i opłacalne narzędzie zwiększania dostępności psychoterapii. Psychoterapia, $3(186), 39-53$

Kavanagh, D. J. (2016). What the problem may be with family intervention ... and with dissemination more generally: a commentary. Australian Psychologist, 51, 69-72. https://doi.org/10.1111/ap.12205

Kępiński, A. (2013). Poznanie chorego. Kraków: Wydawnictwo Literackie.

Kiejna, A., Adamowski, T., Piotrowski, P., Moskalewicz, J., Wojtyniak, B., Świątkiewicz, G., ... Kessler, R. (2015). „Epidemiologia zaburzeń psychiatrycznych i dostępność psychiatrycznej opieki zdrowotnej. EZOP - Polska" - metodologia badania. Psychiatria Polska, 49, 5-13. https://doi. org/10.12740/PP/30810

Kłapciński, M., Rymaszewska, J. (2015). Open Dialogue approach - about the phenomenon of Scandinavian psychiatry. Psychiatria Polska, 49, 1179-1190. https://doi.org/10.12740/PP/36677

Knapp, M., Beecham, J., Koutsogeorgopoulou, V., Hallam, A., Fenyo, A., Marks, I. M., ... Muijen, M. (1994). Service use and costs of home-based versus hospital-based care for people with serious mental illness. British Journal of Psychiatry, 165, 195-203. https://doi.org/10.1192/ bjp.165.2.195

Knapp, M., Beecham, J., McDaid, D., Matosevic, T., Smith, M. (2011). The economic consequences of deinstitutionalisation of mental health services:lessons from a systematic review of European experience. Health \& Social Care in the Community, 19, 113-125. https://doi.org/10.1111/j. 1365-2524.2010.00969.x

Kochański, A. (2016). Koncepcja funkcjonowania środowiskowego centrum zdrowia psychicznego. W: J. Niczyporuk, A. Czernikiewicz, Z. R. Kmiecik, M. Michalak, M. Furtak-Niszczyporuk, E. Czech, ... M. Szewczak, Strategia wdrażania woluntarystycznego modelu środowiskowej opieki psychiatrycznej (s. 297-327). Lublin: Instytut Spraw Administracji Publicznej.

Korzeniowski, L., Pużyński, S. (1986). Encyklopedyczny słownik psychiatrii (3. wyd.). Warszawa: PZWL.

Krawczyk, A., Solarz, A., Wciórka, J. (2015). Otwarty dialog w kryzysie psychotycznym. Medycyna Praktyczna - Psychiatria, 2, 84-91.

Kubacka-Jasiecka, D. (2010). Interwencja kryzysowa: pomoc w kryzysach psychologicznych. Warszawa: Wydawnictwa Akademickie i Profesjonalne.

Lakeman, R. (2014). The Finnish open dialogue approach to crisis intervention in psychosis: a review. Psychotherapy in Australia, 20, 26-33.

Lehtinen, V., Taipale, V. (2001). Integrating mental health services: the Finnish experience. International Journal of Integrated Care, 1(2). http:// doi.org/10.5334/ijic.30

Lenkiewicz, K. (2020). Model EZRA - opieka środowiskowa w leczeniu zaburzeń psychicznych wieku rozwojowego. Dziecko krzywdzone. Teoria, badania, praktyka, 19(1), 155-168.

Lipsey, M. W., Wilson, D. B. (1993). The efficacy of psychological, educational, and behavioral treatment. Confirmation from meta-analysis. American Psychologist, 48, 1181-1209. https://doi.org/10.1037//0003-066x.48.12.1181

Mairs, H., Bradshaw, T. (2005). Implementing family intervention following training: What can the matter be? Journal of Psychiatric and Mental Health Nursing, 12, 488-494. https://doi.org/10.1111/j.1365-2850.2005.00871.x

Malone, D., Newron-Howes, G., Simmonds, S., Marriot, S., Tyrer, P. (2007). Community mental health teams (CMHTs) for people with severe mental illnesses and disordered personality. The Cochrane Database of Systematic Reviews, 3, CD000270. https://doi.org/10.1002/14651858. CD000270.pub2

Meder, J., Jarema, M., Araszkiewicz, A. (2008). Psychiatryczna opieka środowiskowa w Polsce: Raport. Warszawa-Poznań: Instytut Praw Pacjenta i Edukacji Zdrowotnej, Termedia Wydawnictwa Medyczne.

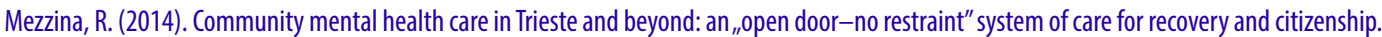
The Journal of Nervous and Mental Disease, 202, 440-445. https://doi.org/10.1097/NMD.0000000000000142

Moskalewicz, J., Kiejna, A., Wojtyniak, B. (red.). (2012). Kondycja psychiczna mieszkańców Polski: raport z badań „Epidemiologia zaburzeń psychiatrycznych i dostęp do psychiatrycznej opieki zdrowotnej - EZOP Polska". Warszawa: Instytut Psychiatrii i Neurologii. Pobrane z: https://ezop. edu.pl/wp-content/uploads/2019/07/EZOP-I_Raport_min.pdf/https://ezop.edu.pl/publikacje/

Mueser, K. T., Bond, G. R., Drake, R. E., Resnick, S. G. (1998). Models of community care for severe mental illness: a review of research on case management. Schizophrenia Bulletin, 24, 37-74. https://doi.org/10.1093/oxfordjournals.schbul.a033314 
Murawiec, S., Litwin, D. M., Seroka, N., Kudlik, A., Sterna, W., Matuszczyk, M. (2019). Nastawienie lekarzy psychiatrów wobec psychoterapii jako formy leczenia zaburzeń psychicznych - ponowne badanie w 2018 roku. Psychiatria, 16, 16-25.

$0^{\prime}$ Connell, M. E., Boat, T., Warner, K. E. (red.). (2009). Benefits and costs of prevention. W: National Research Council (US) and Institute of Medicine (US) Committee on the Prevention of Mental Disorders and Substance Abuse Among Children, Youth, and Young Adults: Research Advances and Promising Interventions, Preventing mental, emotional, and behavioral disorders among young people: progress and possibilities (s. 241262). Washington, D.C.: National Academies Press (US). https://www.ncbi.nlm.nih.gov/books/NBK32767/

Organisation for Economic Co-operation and Development, European Union (2018). Health at a glance: Europe 2018. State of health in the EU cycle. https://doi.org/10.1787/health_glance_eur-2018-en

Ohrnberger, J., Fichera, E., Sutton, M. (2017). The relationship between physical and mental health: a mediation analysis. Social Science \& Medicine, 195, 42-49. https://doi.org/10.1016/j.socscimed.2017.11.008

Olson, M., Seikkula, J., Ziedonis, D. (2014). The key elements of dialogic practice in Open Dialogue. Worcester, MA: The University of Massachusetts Medical School.

Pylkkänen, K. (2011). Finnish psychiatry - past and present. Nordic Journal of Psychiatry, 66 Supl. 1, 14-24. https://doi.org/10.3109/08039488. 2011.590604

Razzaque, R., Stockmann, T. (2016). An introduction to peer-supported open dialogue in mental healthcare. BJPsych Advances, 22, 348-356. https://doi.org/10.1192/apt.bp.115.015230

Razzaque, R., Wood, L. (2015). Open Dialogue and its relevance to the NHS: opinions of NHS staff and service users. Community Mental Health Journal, 51, 931-938. https://doi.org/10.1007/s10597-015-9849-5

Repper, J., Carter, T. (2011). A review of the literature on peer support in mental health services. Journal of Mental Health, 20, 392-411. https:// doi.org/10.3109/09638237.2011.583947

Ritchie, H., Roser, M. (2018). Mental health. Pobrane z: https://ourworldindata.org/mental-health

Rosen, K., Stoklosa, J. (2016). Finland in Boston? Applying Open Dialogue ideals on a psychotic disorders inpatient teaching unit. Psychiatric Services, 67, 1283-1285. https://doi.org/10.1176/appi.ps.201600340

Sartorius, N., Gaebel, W., Cleveland, H.-R., Stuart, H., Akiyama, T., Arboleda-Flórez, J., ... Tasman, A. (2010). WPA guidance on how to combat stigmatization of psychiatry and psychiatrists. World Psychiatry, 9, 131-144. https://doi.org/10.1002/j.2051-5545.2010.tb00296.x

Seikkula, J., Aaltonen, J., Alakare, B., Haarakangas, K., Keränen, J., Lehtinen, K. (2006). Five-year experience of first-episode nonaffective psychosis in open-dialogue approach: treatment principles, follow-up outcomes, and two case studies. Psychotherapy Research, 16, 214-228. https:// doi.org/10.1080/10503300500268490

Seikkula, J., Aaltonen, J., Alakare, B., Haarakangas, K., Keränen, J., Sutela, M. (1995). Treating psychosis by means of open dialogue. W: S. Friedman (red.), The reflecting team in action: collaborative practice in family therapy (s. 62-80). Nowy Jork: Guilford Press.

Seikkula, J. A., Alakare, B., Aaltonen, J. (2001). Open Dialogue in psychosis Il: a comparison of good and poor outcome cases. Journal of Constructivist Psychology, 14, 267-284. https://doi.org/10.1080/10720530126129

Seikkula, J., Alakare, B. (2012). Open dialogues with patients with psychosis and their families. W: Romme, M., Escher, S. (red.), Psychosis as a personal crisis: an experience-based approach (s. 116-128). Londyn-Nowy Jork: Routledge.

Seikkula, J., Alakare, B., Aaltonen, J., Holma, J., Rasinkangas, A., Lehtinen, V. (2003). Open Dialogue approach: treatment principles and preliminary results of a two-year follow-up on first episode schizophrenia. Ethical Human Sciences and Services, 5, 163-182. Pobrane z: http:// jaakkoseikkula.com/wp-content/uploads/2016/05/ehssschizophreniaod2002-1.pdf

Seikkula, J., Arnkil, T. (2018a). Dialog sieci społecznych. Warszawa: Paradygmat.

Seikkula, J., Arnkil, T. (2018b). Otwarte dialogi. Antycypacje. Szanowanie Inności. Podejście terapeutyczne skoncentrowane na sieci społecznej. Kraków: Wydawnictwo Uniwersytetu Jagiellońskiego.

Stockmann, T., Wood, L., Enache, G., Withers, F., Gavaghan, L., Razzaque, R. (2019). Peer-supported Open Dialogue: a thematic analysis of trainee perspectives on the approach and training. Journal of Mental Health, 28, 312-318. https://doi.org/10.1080/09638237.2017.1340609

Thomas, S. P. (2011). Open-dialogue therapy: can a Finnish approach work elsewhere? Issues in Mental Health Nursing, 32, 613. https://doi.org/1 $0.3109 / 01612840.2011 .608314$

Tribe, R. H., Freeman, A. M., Livingstone, S., Stott, J. C. H., Pilling, S. (2019). Open dialogue in the UK: qualitative study. BJPsych Open, 5(4). https:// doi.org/10.1192/bjo.2019.38

Tuori, T., Lehtinen, V., Hakkarainen, A., Jääskeläinen, J., Kokkola, A., Ojanen, M., ... Alanen, Y. (1998). The Finnish National Schizophrenia Project 1981-1987: 10-year evaluation of its results. Acta Psychiatrica Scandinavica, 97, 10-17. https://doi.org/10.1111/j.1600-0447.1998. tb09956.x

van Harmelen, A.-L., Gibson, J. L., St Clair, M. C., Owens, M., Brodbeck, J., Dunn, V., ... Goodyer, I. M. (2016). Friendships and family support reduce subsequent depressive symptoms in at-risk adolescents. PLOS ONE, 11(5): e0153715. https://doi.org/10.1371/journal.pone.0153715

Waterreus, A., Morgan, V. A., Castle, D., Galletly, C., Jablensky, A., Di Prinzio, P., Shah, S. (2012). Medication for psychosis-consumption and consequences: the second Australian national survey of psychosis. Australian and New Zealand Journal of Psychiatry, 46, 762-773. https://doi. org/10.1177/0004867412450471

Wciórka, B., Wciórka, J. (2008). Osoby chore psychicznie w społeczeństwie. Komunikat z badań, BS/124/2008. Warszawa: CBOS. 
Weinmann, S., Read, J., Aderhold, V. (2009). Influence of antipsychotics on mortality in schizophrenia: systematic review. Schizophrenia Research, 113, 1-11. https://doi.org/10.1016/j.schres.2009.05.018

Whitaker, R. (2010). Anatomy of an Epidemic: magic bullets, psychiatric drugs, and the astonishing rise of mental illness in America (1. wyd.). Nowy Jork: Crown.

Ziguras, S. J., Stuart, G. W. (2000). A meta-analysis of the effectiveness of mental health case management over 20 years. Psychiatric Services, 51 , 1410-1421. https://doi.org/10.1176/appi.ps.51.11.1410

ZUS (2020). Wydatki na świadczenia z ubezpieczeń społecznych zwiqzzane z niezdolnościq do pracy w 2019 r. (s. 81). ZUS, Departament Statystyki i Prognoz Aktuarialnych. 